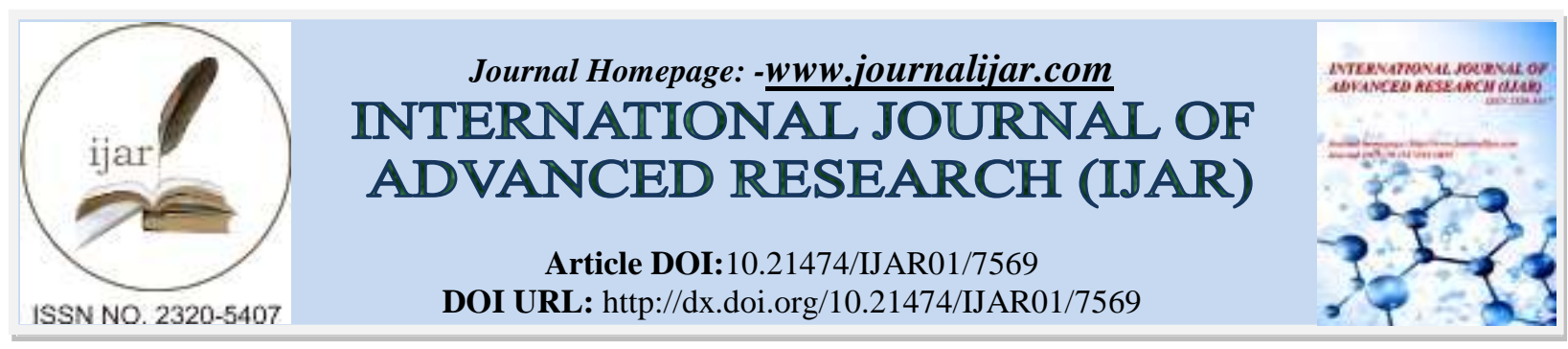

RESEARCH ARTICLE

\title{
PUBLIC SECTOR COLLABORATION MANAGEMENT IN COREMAP IMPLEMENTATION IN KABUPATEN BUTON, SOUTHEAST SULAWESI.
}

Zainul Abidin and Abdul Majid.

Lecturer of State Administration Program, Dayanu Ikhsanuddin University.

\section{Manuscript Info}

Manuscript History

Received: 15 June 2018

Final Accepted: 17 July 2018

Published: August 2018

Keywords:-

Public Sector Collaboration

Management, Coremap, Implementation.

\begin{abstract}
The management of public sector collaboration emerged as an urgent approach adopted by the government at this time because it relates to the demands of the community related to the government's development performance which has not been able to reach the optimal point. The purpose of this study was to describe the implementation of collaborative management between the Buton District Government, including the regions that are now part of South Buton and other actors in coastal resource management, especially in the Coral Reef Management Program. This study uses a case study approach. The results show that the implementation of public sector collaboration management in the coremap program is a collaboration designed by the central government which is then followed up by the Buton District Government together with other parties from both formal and nonformal institutions in implementing the program. The implementation of public sector collaboration management that took place in the framework of the implementation of the coremap conducted from 2006 to 2012 in stages two and three from 2015 to now in the third stage both in terms of definitions, characteristics and processes in general has fulfilled the elements of public sector collaboration management.
\end{abstract}

Copy Right, IJAR, 2018,. All rights reserved.

\section{Introduction:- \\ ChapterI \\ Preliminary:-}

One model of collaboration in government efforts to improve its development performance is by collaborating public management where O'Leary and Bingham (2009) call it "The Collaborative Management". Public sector collaboration management in a governance perspective has several issues that are relevant in the context of public sector management, including in coastal resource management and fisheries. There are several conditions that encourage the promotion of the collaboration principle. First, awareness that development management that only relies on one actor is a practice that is contrary to democratization of development. Secondly, the logic is that by relying on resources only from one party, on the one hand it is difficult to fulfill the needs, on the other hand to waste resources on the other side. Third, the demand that by promoting collaboration in development management the realization of good governance. Therefore, demands from the community so that the regional government must be able to carry out innovations in the management of government become a logical consequence, especially in the context of collaborative management of coastal resource management. 
Departing from the background of the research that has been described, that is how important the Buton District Government carries out the management of public sector collaboration in managing public issues, especially related to the management of coastal resources. Collaboration management in the public sector is principally seen as being able to overcome the scarcity of resources owned by each collaborating party. Likewise, the effect of collaborative management is seen as being able to have the effect of strengthening the competencies of each party that collaborates in order to overcome problems that are still difficult to overcome independently. This study intends to focus on describing the implementation of public sector collaboration management in the implementation of the coral reef management program in Buton District, including in the South Buton section which has now become an autonomous region. Research on the management of coastal resource collaboration with the governance perspective in this study focuses more on the implementation of the coremap program with the first reason, since the establishment of South Buton Regency as a new autonomous region does not have a collaboration program for coastal resource management. There is only a program to distribute fishing vessels for fishermen and other routine programs carried out by the marine and fisheries services. This is quite reasonable because of various limitations as new autonomous regions both human resources and funds. On the other hand, there is a program that was once very massive carried out in the district of Buton as the parent region, the final stage of which is still occurring even on a very small scale in South Buton district as a new autonomous region. The program is called coremap. Therefore the discussion of this research will occur with the locus of Buton and South Buton District, which cannot be separated from one another. Although the discussion of this research will focus a lot on the shading or the southern part of Buton with the focus there will also be more second phases, although as a whole the first and third phases will also be discussed.

\section{Chapter II.}

\section{Literature Review}

\section{A. Public Sector Collaboration Management}

Changing perspectives and orientations in running the government from government to governance causes the attention of experts and practitioners to be more focused on the form of organizations that are capable of possessing capabilities and at the same time being able to reach beyond their authority. As a result of these changes, a government leader at all levels must also want to change, especially in terms of management capabilities and the desire to direct their attention to efforts to integrate and collaborate with other organizations in completing their development programs. This new perspective by O'Leary and Bingham (2009) is called the collaboration management (The Collaborative Management). Collaboration itself can be defined as the involvement of various parties with different institutional origins in an implementation of a development plan. The emphasis of collaboration is the different origins of the parties involved. With these different origins, an implementation of development will involve resources.

The promotion of the principle of collaboration in development management is accelerated by two epochs that define current development, namely globalization and decentralization. Globalization, although ideologically relying more on market mechanisms and private actors to finalize capitalism, is also pragmatically confronted with the urgency of finalizing state facilitation. In addition, agents of capitalism are also very aware of the threat of investment insecurity for capitalism if civil society marginalized in the praxis of development, therefore globalization also promotes the principle of collaboration in development management. Decentralization, which has the consequence of down-sizing development management, is also concerned with the promotion of the principle of collaboration, because when the development unit is more localized the resources of each party are also increasingly limited, especially the state. Because of this, the spirit of decentralization also finally trapped in the inevitability of collaboration. Regional autonomy, management of local resources to solve problems/local needs, are very much determined by managerial abilities in collaborating between development actors (Salman, 2004).

Associated with development management, the benefits of collaboration are not only related to the technical benefits of collaboration between actors in the implementation process, but especially on the resources emerging (emerging resources) produced by the collaboration. Based on experience in various cases, the benefits of collaboration in development management can be described as follows. First, collaboration presents new contributors to development management. With limited contributors, the burden is very large. At present, the resources owned by the government do not allow it to become a single contributor to development. The presence of private contributors and civil society in an area reduces the burden. Second, collaboration presents new resources, both physical and non-physical. Third, collaboration creates social capital. Social capital is the ability of development actors to organize and coordinate actions towards achieving goals. 


\section{B. Understanding Coremap and Coremap Program Implementation in Buton District}

Coremap is a coral reef management program abbreviation. The COREMAP program is an effort to manage coastal and archipelago resources, especially coral reef ecosystems and fish resources in a sustainable manner, in order to improve the welfare of coastal and island communities. The importance of managing these resources can be seen from the results of a study which shows that in managed coral reef ecosystems 30 tons of fish can be produced per $\mathrm{km}$. This value can be sustained if this resource is managed properly. Conversely, if the coral reef ecosystem is left to be damaged the results can drop dramatically to 5 tons per $\mathrm{km}$. COREMAP itself emphasizes more on efforts to improve institutional and community capacity and the development of various alternative community activities in an effort to meet their needs from the sustainable use of coral reef ecosystem resources.

Buton Regency before divided was one of the COREMAP target areas in phase I to Phase III. Coremap in Buton district as in other regions is divided into 3 phases, coremap I, II and III. Coremap I is the initial stage of regulation from coremap. Coremap I explained the purpose of the meeting through socialization to regions and establishing a legal basis and encouraging local governments to be active in managing coral reefs. Coremap I has succeeded in Buton District. This starts from the establishment of the basic regulation of the implementation of the theme, which is the decree of the district head of Buton number 677 of 2006 concerning the management of coral reefs. The Buton District Government through the Decree of the Regent of Buton Number 1578 of 2006 has determined Liwutongkidi Island as a Regional Marine Conservation Area (Buton COREMAP II Report, 2007).

In phase II it was carried out since 2006. Previously the COREMAP Phase 1 program for Buton District was carried out since 2005, with the target area of one subdistrict namely the District of Lakudo. The COREMAP II target area consists of 7 sub-districts, from each subdistrict, four COREMAP target villages are determined. Determination of the target area is based on the Regent's Decree, by prioritizing the lagging regions (Buton COREMAP II Report, 2007). In the implementation of phase II, various villages form marine protected areas (DPL) which will be determined in various Village Regulations. The Coremap III program itself ran four years ago and is still running with the institutionalization stage. The final section of the COREMAP (Institutionalization) program aims to establish a reliable and operational coral reef management system, decentralized and encourages strengthening.

Coremap is a comprehensive program approach, combining approaches that bring together top down and bottom up. Coral reefs are protected and conserved, through natural rehabilitation efforts while the community is inspired to participate in maintaining and utilizing resources wisely and wisely. In the context of Buton Regency, the activities of community groups to support Coremap II were also carried out in various ways such as training in dodol processing from seaweed, conducting training in processing fish into Abon. The training is always attended by various members of the Pokmas (Community Group). The existence of community groups in the fields of cultivation, fishing, processing, marketing and supervision groups provides benefits for group members (ButonCoremap II, 2012 Report).

\section{Chapter III}

\section{Research Methods}

This study uses a qualitative approach. Qualitative research is research that focuses on interpretation (Creswell, 2003). Research strategy used in case studies. Data analysis used in the study was an interactive analytical model of Miles and Huberman (1994). This model includes data reduction, data presentation, conclusion and verification. Data is presented in the form of text narratives to describe what happened. The author makes initial conclusions and performs data verification that is presented by confirming through triangulation.

\section{Chapter IV \\ Results and Discussion:-}

A. Implementation of Public Sector Collaboration Management Between Buton District (Including South of Buton) Government and Parties in Coremap Implementation

In the context of collaborative management in coastal management in the coremap program in Buton District, including part of the area that is now part of South Buton, is a synergistic policy and program and needs to be implemented properly. Therefore, the Buton District Government is trying to make this happen. Conceptually it can be understood that there is no single organization/government that is able to meet its needs by using resources that are owned independently. 
The researcher tried to describe the implementation of public sector collaboration management that took place between the Buton District Government and other parties in supporting the achievement of coral reef conservation, carried out through the disclosure of various facts in the field by digging up information about, among other things, how the idea emerged to collaborate. who first took the initiative to collaborate, what is the basis for the consideration of both parties to collaborate, do they understand the context so that they want to collaborate and how the process is so that the decision to collaborate.

In the context of coremap initiated by the central government, the program design is designed in a participatory and collaborative framework. Participation in COREMAP is active community involvement, especially fishermen and coastal communities, at every stage of COREMAP activities, starting from preparation, pre-planning, planning, implementing, monitoring and evaluating activities.

In the context of Buton district to follow up on the central direction and as a basis for implementing the coremap, the local government in this case the regent issued a Decree of the Regent of Buton number 677 of 2006 concerning Management of Coral Reefs which later followed up by the decision letter of the Buton district marine and fisheries number 24/ Q / VI / 2007 which regulates the organization, the main tasks of the party structures involved in coremap implementation. As for the reference, among others, Law No. 32 of 2004 concerning Regional Government, Decree of the Minister of Maritime Affairs and Fisheries No. 38 Men/2004 on General Guidelines for the Management of Coral Reefs and Decree of the Minister of Maritime Affairs and Fisheries Number Kep. 13 Men/2006about the establishment of a Steering Committee, the Technical Committee and the Management of the Coral Reef Rehabilitation and Management Project.

In the context of collaborative management for the implementation of coremap in Buton district (including South Buton) with related parties due to the decision of the Ministry of Maritime Affairs and Fisheries which appointed several regions, including Buton district to implement coral reef conservation programs in the Coremap program. Therefore, the Buton District Government through a regent's decree and followed by a decree from the head of the maritime and fisheries service followed up on the order by involving the level of the organization or government under its authority. Where both theButon District Government and the marine and fisheries services and related agencies, sub-districts and villages, the community and related parties are obliged to succeed the instruction.

Departing from the instruction, it was then followed up by the maritime and fisheries service by holding a meeting and making a joint agreement at the level of the government that carried out the collaboration. At the village level, the initial idea so that the idea to collaborate in the framework of the implementation of coremap in South Buton as revealed by the informants included the head of the Bahari village of Sampolawa sub-district during the coremap program which stated that :

"Our involvement in a collaborative collaboration is a follow-up to the Regent's decree and the head of the maritime and fisheries service and mutual agreement between DKK and all relevant parties. Subsequently the regent and the head of the DKP office and the related SKPD collaborate with stakeholders to succeed in this program (L, 8 June 2018)"

In addition to information about who initiated the collaboration management of the public sector in the coremap program, it is also important to know what is the basis for the consideration of various parties so that they collaborate. Departing from the information gathered from various informants and documentation, it can be concluded that the basis for the consideration of why many parties include the Buton District Government, fisheries maritime service, transportation services, environmental services, sub-district and village governments, NGO members, private and community due to consideration other than refers to the regent's decree instructions and the decree of the head of the maritime and fisheries service that had been signed were also due to the consideration that the Buton District Government was given the mandate by the central government as one of the proponents of coral reef conservation. Therefore, the Buton District Government must continue to maintain coral reefs as a permanent fishery center in Southeast Sulawesi and even increase their production from existing ones. The role of Buton Regency (in this case including South Buton), can be a mainstay of how to maintain coral reefs without disturbing the lives and welfare of coastal communities on the other hand, where coral reefs that are maintained and even increase can be a guarantee for the long term.

Related to how the process is so that the decision to collaborate between various parties in the meeting in Buton District can actually be understood through the explanation of who initiated and the substance of the purpose of the 
collaboration. As explained earlier that this collaboration occurs because of an order or instruction from above or topdown from the minister of maritime and fisheries decree that was followed up by the regent and the maritime and fisheries service of Buton Regency. Then followed up through mutual agreement and joint meetings between stakeholders. However, the top down orders or instructions are complemented by proposals from the parties from below in some ways or bottom up. This was revealed by the head of program and coastal affairs of the South Buton Marine and Fisheries Department which stated that :

" Our collaboration process refers to the regent's decree and the fisheries marine service decree and mutual understanding between the parties at the district level and its coordination to the center so that it adapts to the conditions and capabilities of the parties and staff (N., June 2 2018)".

However, the interesting information from the head of the satker coremap stated that there were still those who were not ready to commit to collaborating at the service level directly related to this program. This condition is certainly quite influential because it is related to field readiness when the program is implemented. This can be seen from the lack of effective coordination mechanism. Many schedules that should be carried out on time are finally delayed. Likewise at the village level there are villages that actually entered in the initial draft refused to be involved and some were involved but were less active in activities. Resistance in the form of unwillingness or laziness at the service level can be caused by the absence of benefits that can be obtained or perhaps their interests are not accommodated. At the village level there is resistance because it is considered to disturb their livelihoods in the short term and is familiar with the existing habit patterns.

In addition to how the process of collaboration occurs, also information about what forms of collaboration are part of the substance of the description of collaborative management. Based on the information obtained from various informants, it can be concluded that the form of collaboration that exists between various parties is in the form of support from parties in the structure to the Buton District government.

Further about how the forms of cooperation between the Buton Patent Government and various parties can be traced through the contents of the Decree of the Head of the Marine and Fisheries Department Office and the Joint Statement of Understanding between various parties regarding the support of the achievement of the target program where all parties agreed to succeed in achieving the goals and objectives wherein each party expresses its commitment to its contribution, for example, that the First Party in this case, the central party and the regional government, develops targets, regulations and general guidelines, infrastructure and costs for its implementation. Further explained in the statement that the parties are willing to help and support this program through supervision activities, carrying out mentoring, counseling and awareness, socialization and arousing and mobilizing community participation.

Related to how the process of formulating strategies, objectives, and targets as the national program has actually been compiled by the main person in charge in this case the marine and fisheries department assisted by Indonesian science institutions. In general COREMAP's goal is to ensure the availability of reef fish resources and to conserve their habitat (coral reefs) on an ongoing basis, as the main wealth and capital of coastal village development, to accelerate poverty reduction through increasing community and institutional capacity in the implementation of village and / or inter-village development and increasing provision socio-economic facilities and infrastructure in accordance with community needs. areas that have long existed. The specific objective or target is to first empower coastal communities and their institutions in the COREMAP region to be able to conserve coral reefs and other related ecosystems through joint management with government institutions. Second, increasing income through transparent business diversification, accountability and feasibility to be financed and thirdly increasing the government's active role in meeting the needs of coastal communities in the framework of joint management of marine protection and marine protected areas (DPL).

From the objectives, the COREMAP Strategy was mapped where the strategy was through the involvement of various stakeholders in the management of coral reef resources, the implementation of activities supported by COREMAP that needed to involve stakeholders, especially fishermen and communities whose lives depend on coral reef resources and other resources. The management of coral reef ecosystem resources is not only related to the procedures for utilization, but also by other things that affect the use procedures, all of which involve various stakeholders at different levels (national, provincial, district and village), including policy makers, universities, NGOs, fisheries businesses, fishermen associations, law enforcement. That way, the presence of stakeholders together by knowing their roles and functions in the context of managing coral reef ecosystem resources will 
facilitate the implementation of a responsive management model, oriented towards sustainable use and encourage the welfare process of fishing communities.

In order for a collaboration to have a clear direction and be a guide for all parties and can be realized, in the context of collaborative collaboration in Buton regency there is nothing specifically in the form of vision, policies, strategies, goals and common goals. The vision and mission in the coremap program in all regions refers to the vision - mission set by the center or the program as a whole. The vision of this program nationally is ensuring the sustainability of coral reef resources and the welfare of local communities through the application of the principles of environmentally friendly sustainable management and the development of economic enterprises for the local community. This is actually strengthened carefully from the regent's decree and the decree of the head of the maritime and fisheries service, so it can be concluded that the collaboration has a vision as expressed by the head of the coremap work unit "... realizing sustainable coral reef management $(\mathrm{H} ., 29$ June 2018)". This vision is actually intersecting and is a description of the vision in the field of fisheries in Buton Regency namely: as a pillar of sustainable and competitive fisheries. In order for this vision to have a clear direction then it will be accompanied by a mission that includes: 1) increasing sustainable fisheries production; 2) optimization of infrastructure by encouraging optimization of fisheries resources and) improving the welfare of coastal communities and fishermen. Departing from the vision and mission, then it became a reference and director of collaboration in realizing the achievement of coremap targets, especially in sustainable management of coral reefs.

Related to what policies are issued from the collaboration to support the effectiveness of the implementation of the collaborations that have been agreed upon, the duties of the regent and the fisheries marine service are clearly stated in the duties of each party involved in the collaboration. Another policy is that each government agency in the related districts, sub-districts and villages is emphasized to collaborate with other relevant parties to support the implementation of the coremap program and the agreements that have been stated in the meetings and meetings.

The policy that becomes the technical reference above is derived from the policies that have been issued by the central government the marine and fisheries department, namely: 1) integration and coordination between relevant agencies, including universities in supporting sustainable coastal resource management; 2) strengthening the policy network; 3) assistance and escort program.

The composition of organizational personnel in implementing collaboration between the two parties can be illustrated through the contents of the regent's decree and the maritime and fisheries department and the agreement signed in the meeting which certainly refers to the technical guidelines and written instructions of the program but also through a series of information sourced from informants. The Regent acts as the party who is committed in encouraging the policy of the leadership to remain consistent to realize the agreed targets.

As the technical executor, the Head of the Marine and Fisheries Service, the head of the coastal empowerment council and the head of the work unit coordinate again with the province and the main center. In addition, the inner city district government consists of the marine and fisheries service, the Environment Agency, Bappeda, Community Empowerment, Spatial Planning assisted by Universities, NGOs, sub-district and village governments and the community acts as the party implementing the coremap program. In Buton Regency as the Regency that implemented the program, the organization has an organizational structure consisting of a coastal community empowerment board, a national park, and a project management unit as the manager whose determination is determined by the regent's decree. In the implementation of the regent and regional legislative council will provide support for the effectiveness of the role and institutional functions of the coremap.

In full, the organizational structure is led by a coastal community empowerment board where the coastal community empowerment board is formed through the Decree of the District Head and chaired by the Regent or Chair of the District Bappeda. This board consists of 20 people with a balanced composition that comes from government and non-government elements in this case from the government element from the elements of DKP, Bappeda, DinasPendidikan, KSDA, Police, Navy, Camat. In addition, members can also be added from the Bapedalda office, the Tourism Office, the empowerment and spatial planning agencies. there is also the village head fishermen, women, community leaders, traditional leaders, NGOs, and universities. The second element is the project management unit which is chaired by the Head of the DKP or other services that handle maritime and fisheries functions. Third, the power of the user of the unit's management program budget. In each sub-district, senior extension facilitators will be placed extension and training officer (SETO) which is assigned, among others, to assist 
PMU in the implementation of the COREMAP program and coordinate activities to be carried out by the Facilitator and Village Motivator. Community Facilitators (CF) and Village Motivators Community Facilitators (CF) and Village Motivators recruited and placed in the village to assist in the implementation of the COREMAP program in the village (General Guidelines for COREMAP Community-based Management, 2006).

In the context of collaboration in the match program in Buton District acting as the collaboration leader was the coastal empowerment council chaired by the buton regent and the head of the bappeda and assisted by the executive management unit chaired by the head of the maritime and fisheries service and the daily was run by the head of the work unit as the main actor of collaboration. This can be traced through information from informants and based on the decree of the regent and the maritime and fisheries service and mutual understanding.

Related to the mechanism of responsibility of each party that collaborates takes place as stipulated in a joint decree and agreement that is strengthened by a meeting agreed upon and signed by each party. Information is obtained that at the district level the mechanism of responsibility can be seen in several articles in the district head and marine and fisheries services as well as the MoU. Head of the program and coastal area of South Buton Regency stated that :

"The technical responsibility for activities and funding is carried out by the central marine and fisheries department which has been decentralized to the main implementers here, namely the coastal empowerment council chaired by the regent and the head of the bappeda and the management unit which is headed by the head of the regency. This is in accordance with the rules and skills that have been agreed upon (N., June 17, 2018 ".

In order for these responsibilities to be carried out according to the agreed terms, coordination is always carried out according to their respective functions. For example, between management units and coastal empowerment councils and the central government. Coordination took place at the sub-district level between sub-district heads and subdistrict level administrators as well as at the village level facilitators and village motivators will always coordinate with village heads and community leaders. The form and mechanism of coordination are carried out through meeting activities and follow-up in the field.

Based on the foregoing description, it can be concluded that the implementation of public sector collaboration management in the coremap program is a collaboration designed by the central government which is then followed up by the Buton District Government where South Buton is still a part. Together with other parties both from formal institutions in the sense of service related also to non-formal institutions such as members of non-governmental organizations, community and adat leaders in the sub-districts and villages that are the location of program implementation. As is known that even though the order to collaborate comes from the central government and the Buton District Government as the parent of South Buton District since the beginning of implementing collaboration by involving a number of parties. Therefore, the Buton District Government and in this case including the government in southern Buton can be categorized as a government that has adopted a governance governance approach. This is because governance is susceptible to use because of the internal awareness of an organization in this case the government that by relying on its internal resources it is impossible for the organization the government is now able to achieve its vision and mission.

Use of other organizational resources is important. Therefore at the same time when the local government has invited other resource owners that are needed by their government, it means that they have implemented the substance of governance, namely the importance of using networks and collaboration between actors. This is in line with the views of O'Leary and Gazley (2009) which states that governance that collaborates management is one of the characteristics of government organizations that apply the concept of governance. The desire of Buton District Government to utilize the network, how to make decisions with networks, how to determine tasks and targets with the network, and how to manage the impact of the policies made shows that the efforts made between the Buton District government followed by the southern Buton district as a division with various parties are categorized as a form of collaboration management.

The process that occurs in implementing the implementation of this program is one part of the obligations of the Government of Buton District and South Buton as a division in facilitating its citizens to be able to manage coastal resources in a sustainable manner and improve their standard of living which further aims to solve problems that cannot be resolved or resolved. by relying on himself. This process is in line with the definition of collaborative management proposed by O'Leary and Gazley (2009) that organizations in the context of governance must be 
oriented to organizations that act to facilitate and be able to operate in networks between organizations to solve problems that cannot be solved by themselves, or are able to finish easily compared to the organization itself.

An important aspect is analyzed in the context of collaboration between the Buton District Government and the terikait government, namely whether there is reciprocal interest. Field findings indicate that there are interests of various parties who want to be achieved with a sustainable coral reef management program in a coremap. The main interests of the Buton District Government as the parent and South Buton as pemekaran are overcoming the destruction of coral reefs and maintaining and even increasing the position as a fishery barn in Southeast Sulawesi in sustainable management of resources. While the objectives to be achieved from the parties so that they are willing to provide their resources to succeed in the coremap program are diverse, but overall there are parts of efforts to realize sustainable management of coastal resources and fisheries. Based on these interests, one meeting program activities achieved the achievement of the coremap target. The interests that collaborate in realizing sustainable management of coral reefs and coastal resources are in line with what was stated by Hull in Hjern, (1987).

Thus it can be concluded that the description of the implementation of public sector collaboration management that took place in the framework of the implementation of the coremap conducted from 2006 to 2012 in stages two and three from 2015 to the present in the third stage both in terms of definition, characteristics and processes in general public sector collaboration management. Except for some aspects that are still not optimal in their implementation so that they have implications for outputs or targets that have been predetermined as previously described, for example coordination and communication.

\section{Chapter V \\ Conclusion:-}

The process that occurs in implementing the implementation of this program is one part of the obligations of the Government of Buton District and southern Buton as a division in facilitating its citizens to be able to manage coastal resources in a sustainable manner and solve problems that cannot be solved by relying on themselves. This process is in line with the definition of collaborative management proposed by O'Leary and Gazley (2009) that organizations in the context of governance must be oriented to organizations that act to facilitate and be able to operate in networks between organizations to solve problems that cannot be solved by themselves, or are able to finish easily compared to the organization itself.

Field findings indicate that there are interests of various parties who want to be achieved with a sustainable coral reef management program in a coremap. The main interests of the Buton District Government as the parent and South Buton as pemekaran are overcoming the destruction of coral reefs and maintaining and even increasing the position as a fishery barn in Southeast Sulawesi in sustainable management of resources. While the objectives to be achieved from the parties so that they are willing to provide their resources to succeed in the coremap program are diverse, but overall there are parts of efforts to realize sustainable management of coastal resources and fisheries. Based on these interests, one meeting program activities achieved the achievement of the coremap target. The interests that collaborate in realizing sustainable management of coral reefs and coastal resources are in line with what was stated by Hull in Hjern, (1987).

Thus it can be concluded that the description of the implementation of public sector collaboration management that occurs in the framework of the implementation of the coremap conducted from 2006 to 2012 in stages two and three from 2015 to the present in the third stage both in terms of definition, characteristics and processes in general have met the elements public sector collaboration management. Except for some aspects that are still not optimal in their implementation so that they have implications for outputs or targets that have been predetermined as previously described, for example coordination and communication. 


\section{Bibliography:-}

1. COREMAP II. 2012. Report of the Implementation of the 2012 COREMAP II Local Research Implementation Activity of Buton District.

2. COREMAP II. 2007. Report of Buton District 2007 COREMAP II Local Research Implementation Implementation Report.

3. COREMAP II. 2007. Report on the Preparation of KKLD Plan Management in Liwutongkidi.

4. Creswell, W. Jhon. 2003. Research Design Qualitative \& Quantitative Approach, Sage. London-New Delhi.

5. Ministry of Maritime Affairs and Fisheries of the Republic of Indonesia. Decree of the Minister of Maritime Affairs and Fisheries No. 38.Men/2004 on General Guidelines for the Management of Coral Reefs

6. Ministry of Maritime Affairs and Fisheries of the Republic of Indonesia. Decree of the Minister of Maritime Affairs and Fisheries Number Kep. $13 / \mathrm{Men} / 2006$ about the establishment of a Steering Committee, the Technical Committee and the Management of the Coral Reef Rehabilitation and Management Project

7. Department Of Marine And Fisheries, Buton Regency, 2007. Decree Of Marine And Fisheries Office Number 4/Q/VI/2007 About The Structure, Organizational Structure And Main Tasks Of The Implementation Of Coremap In The District Of Buton.

8. Directorate General of Marine, Coastal and Small Islands Ministry of Maritime Affairs and Fisheries. 2006. General guidelines for COREMAP community-based management.

9. Hull, Christopher J., with Benny Hjern. 1987. Helping Small Firms Grow: An Implementation Approach. London: Croom Helm.

10. Miles, Mathew and Huberman, 1994. Qualitative Data Analysis An Expanded Sourcebook. California: Sage Publication, Inc.

11. O'Leary, R., B.Gazley, B. Michael McGuire, and L.B.Bingham. 2009. Public Managers in Collaboration. In The Collaborative Publik Manager: New Ideas for the Twenty-firts Century. 1-12. Washington DC: Georgetown University Press.

12. Kabupatenbuton Government. Decree Of The Regent Of Buton Number 677 Of 2016 Concerning The Management Of Coral Reefs In Buton Regency.

13. Salman, Darmawan.2004. Collaboration Between Actors in Regional Economic Development "Paper Presented In A Seminar On Population-Based Regional Economic Development Planning", Development And Population Education And Training Center For Education And Training Agency Of The Ministry of Home Affairs. Jakarta: 4 - 9 October 2004. 